\title{
Difficulties of Academic Achievement in Principles of Accounting Courses from the Student Perspective: Evidence from Libya
}

\author{
Mohamed M. Tailab ${ }^{1}$ \\ ${ }^{1}$ Lincoln University, Oakland, CA, USA \\ Correspondence: Mohamed M. Tailab, Lincoln University, 401 15th Street, Oakland, CA 94612, USA. Tel: \\ 1-510-213-4365. E-mail: Tailab2010@gmail.com
}

Received: December 9, 2012 Accepted: August 14, 2013 Online Published: September 22, 2013

doi:10.5539/hes.v3n5p36

URL: http://dx.doi.org/10.5539/hes.v3n5p36

\begin{abstract}
Many studies by researchers and accounting educators explore various factors associated with the success or failure of accounting majors in college level accounting courses. This paper identifies and summarizes the main obstacles associated with low student academic achievement in introductory courses in the College of Accounting at Al-Jabal Al-Gharbi University, Libya. The research empirically investigates student perceptions of the difficulties of academic achievement in principles of accounting courses. The research method was a survey that involved classifying students as either accounting majors or non-accounting majors. Data was collected through a questionnaire with 28 items related to five primary groups: an instructor's teaching style, exams and quizzes, students, accounting textbooks, and general groups plus one open-ended question. Findings show that the major obstacles of learning and source of negative perceptions students have toward accounting courses are: lack of teaching assistants, lack of computer laboratories and computer applications, crowded dormitories, lack of interaction between students and faculty, a gap between what is taught and practical applications, irrelevant textbooks and exams, and lack of proficiency in English. Solutions offered include: greater emphasis on teaching computer accounting technology, improving effectiveness of accounting instructors and textbooks, and offering pre-college accounting courses. This study focuses on one public university, which limits its generalisability. For future research, the author suggests interviews with students upon collecting their questionnaires to elicit more complete responses, and greater attention to perspectives based on gender in order to discover and understand any differences among male and female attitudes toward accounting courses.
\end{abstract}

Keywords: academic achievement, learning obstacles, student perception, introductory accounting, attitude

\section{Introduction}

According to the policy of the College of Accounting at Al-Jabal Al-Gharbi University-where this study was conducted - all students must take Principles of Accounting 130 and 131 during their first year. Students who intend to major in accounting have to pass these core courses with a minimum grade of $\mathrm{C}$. These courses are required for a variety of majors (accounting, management, economic, and data analysis), and many of the students who enrolled in these courses have never studied accounting before. Lecturers noticed that these accounting students tend to have a negative attitude at the very beginning and assume that accounting is an extremely difficult subject. The College's instructors agreed that academic achievement in these basic accounting courses was very low. Based on the author's experience as a lecturer at Al-Jabal Al-Gharbi University, many students dropped or failed the course or had to repeat it to get a passing grade. This observation encouraged the researcher to explore student difficulties in academic achievements. This study, therefore, attempts to identify and summarize the main potential obstacles that may be associated with low student academic achievement in introductory courses in the College of Accounting at Al-Jabal Al-Gharbi University.

\section{Background of Libyan Business Education}

There are a number of developing countries (including Libya) that inherited their accounting education practices from a colonial system. The Libyan education system in general and accounting education in particular were imported (if not completely inherited) from western countries like the UK and the US (Ahmed, 2004).

The accounting education system in Libya developed in two stages. The first stage was before independence; when there was no formal accounting education, no training for the local population (Buzied, 1998). Under 
colonial rule, less than $10 \%$ of the Libyan population was literate. Thus, few Libyans had been given the chance to study at a university or to qualify for a recognized profession at the time of independence.

During the second stage, the Accounting Department in the College of Economics and Commerce at Libyan University established the first accounting education program in 1957 with 48 students and 10 instructors. The accounting curriculum from 1957 to 1976 was greatly impacted by the British education system, as Libya was administered by Britain from 1943 to 1952, and many accounting faculty members were educated in the UK. Since 1976, the American accounting program model has replaced at the Faculty of Economics and Commerce at Libyan University. Both systems are similar in what they focus on particular on the technical or mechanical aspects of financial accounting, dealing with external reporting, taxation and external auditing. On the other hand, the difference between them is their orientation approach. Bait-El-Male et al. (1973) showed that the early program in the College of Economic and Commerce at the Libyan University was entirely British orientated because the teachers and professors were from Egypt which already was impacted by the British accounting system, while the second one is American orientated. Little attention has been given to combine the accounting education system with Libya's environmental requirements (Buzied, 1989; Ahmed, 2004).

Education in Libya is primarily free, with housing highly subsidized as well. Recently, some private and for-profit colleges opened their doors for business and other types of education.

The Libyan system of post-secondary and higher education is controlled and managed through the Ministry of Education. After graduation from high school, the Ministry of Education determines which college students will attend. The Ministry of Education makes such determinations based on projected needs for the country. The Libyan system of colleges and universities was designed to accommodate regional and cultural concerns and the needs of the community, and thus most students are directed to a regional university that fits those needs. Males and females attend classes together but live in completely separate housing. Students admitted to business schools must have a high school diploma with a Grade Point Average (GPA) of about 3 on a 4-point scale. Exceptions are made regarding the required GPA for admission to some students from rural regions.

Students must earn at least 140 credit hours to graduate. The bachelor degree program usually requires a minimum of four years to complete; two semesters per year with one week of extracurricular activities. To graduate, Students must have a GPA of C (2.00 points or 60-64) or better by the end of the program. If the GPA goes below $\mathrm{C}$, a student will be notified by the admissions office. If the GPA remains below $\mathrm{C}$ for three consecutive semesters, a student will be suspended from the University.

The evaluation policy normally requires three exams each semester; two during the semester and one final exam. The final exam counts for $60 \%$ of the semester points, $30 \%$ for the two midterms, and $10 \%$ for homework, attendance, and participation.

Unlike the education style in developed countries, the dominant feature of the Libyan educational style is indoctrination where the instructor explains and the students listen. The Libyan business universities, therefore, tend to put more emphasis on acquiring facts than developing critical-thinking skills (Kilani, 2000).

\section{Previous Work}

Several studies have been conducted to address various aspects of the introductory accounting course. Among other things, these studies have examined the determinants of student performance in the principles of accounting courses (Ogilby, 2000, p. 4). Abraham (1987) was unable to identify any significant correlation between the use of the computer and student performance.

The effect of instructional media and materials techniques such as chalkboard, overhead projector, and computer-projected software on the performance of students was investigated by Beets and Lobingier (2001) who found no evidence of overall differences in student learning using the three techniques mentioned above. Young (2004) reported that utilization of PowerPoint slides by a lecturer made attendance suffer. Nouri and Shahid (2008) indicated that students have a significant understanding when an instructor uses a PowerPoint section of an Accounting Principles II despite the fact that they stated no important variations on entertainment among the PowerPoint and traditional sections of the course.

As far as exams are concerned, Porter and Lawler (1968) showed that there were some factors such as effort, abilities and traits impacted on a student's examination score. Reed and Holley (1989) scrutinized the influence of the schedule of final examination on a student's academic achievements. They pointed out as a conclusion that students of introductory accounting faced deterioration in examination performance as both the exam week and the exam day progressed. Additionally, Elikai and Baker (1988) indicated if the quizzes are worth a significant part of a course grade, it can enhance students' performance in accounting. Similarly, Almer et al. 
(1998) stated that a student's score in introductory accounting based on essay quizzes was higher than one-minute paper quizzes. Likewise, Brink (2013) showed that utilizing both pre- and post-lecture quizzes can lead to improved student preparation, increased student participation during class discussions, more effective use of lecture time, and significant enhancement in students' academic achievements on Intermediate Accounting II subsequent examinations.

Some studies examined students' attitudes toward accounting (Weinstein, 1999, p. 2). Solomon (1975) found that the perception of introductory accounting toward accounting was improved by using the case method although there was no lasting effect because of the discontinued method. This study did not examine the influence of student attitudes at the beginning of the course. Atieh (1997) showed that the Saudi Arabian students have a negative attitude toward accounting, considering it a difficult subject.

Some studies scrutinized the relationship between foreign language (e.g., English) in accounting education and student performance, such as Ayers and Peters (1977) who confirmed that the academic success can be positively influenced by the English language proficiency. However, Jochems (1991) reported that the performance could have been low, if the foreign language has been taken a place in education.

The length of a semester plays a role on student learning. Austin and Gustafson (2006) found that students who took intensive courses had higher grades than those who took traditional sixteen-week semester courses. They wondered whether this difference was due to student effort or because of the structure of summer courses. Likewise, the average number of credit hours has been analyzed by Sayel and Quraan (1994) who pointed out that performance in both Principles of Accounting 101 and 102 have been negatively affected by the number of credit hours in each course. This relationship -the number of credit hours and the performance - was significant in Accounting 101, but not in Accounting 102.

At the time of Libyan independence, in 1951, the accounting profession did not exist in Libya, and most businesses relied on foreign accounting firms from Italy and the UK (Bait-El- Mal et al., 1973). Fifteen years later, Kilani (1988) confirmed as well that accounting education and the accounting profession in general, were oriented toward the systems of the UK and USA, and thus more relevant to the environment of those countries than to the Libyan environment. Ben-Garbia (1990) studied the integration of the accounting profession and business education, and concluded that the existence of competent teachers, modern textbooks, and an effective educational system should produce qualified graduates for the new era in Libya.

In addition to the contributions of these researchers, some business schools have also been addressing the performance of accounting education. Until 1995, the courses of principles of accounting at Al-Jabal Al-Gharbi University were taught in small lecture sections ranging from 25 to 35 students; both were three credit hour courses that meet once a week. So, the College conducted survey to measure students' perception regarding meeting three hours each week. The survey was distributed by hand to a poll sample group of students. At the end of a lecture, the selected set of students brought the completed versions back to an instructor. The survey collected primary data from the spring 1993 classes of advanced accounting and non-accounting major. The total number enrolled in these courses was approximately 1200 students, and the random sample was $30 \%$. This was a preliminary study with the purpose of improving students' quality of education, their perception about their education, and to address their concerns.

As the business education and economic development, Kilani (2000) examined the role of the Libyan educational system and how it could help improve Libyan economic and social developments. He pointed out that business education programs should focus on curriculum and lectures in order to develop the critical skills of students. Also, Al-Daly (2003) attempted to identify the key role of the Libyan business education program to enhance student performance in undergraduate accounting courses by emphasizing a significant correlation between the curriculum and the academic students' achievement. Al-Hanon (2004) pointed out that there is no compatibility between the accounting curriculum and the needs of the Libyan environment. This is the same finding that Shareia (2010) found when he pointed out that the accounting profession in Libya experiences educational and legal challenges if it is to achieve its potential in helping the country reach its economic goals.

\section{Research Aim}

The research objective is to identify and list the negative perceptions of Libyan students toward introductory accounting courses in relation to academic performance.

\section{Research Method}

The type of research method adopted in this study was a survey design. The target population was all students who enrolled in the 2006-2007 academic year. Of the 805 total students enrolled at that time, 150 were excluded 
from the search because they had not taken Principles of Accounting 131 by the time the questionnaire was distributed. Therefore, the total number of students (population) was 654 students who had already completed Principles of Accounting 130 and 131 in the College of Accounting at Al-Jabal Al-Gharbi University. A random sample of 180 students received the questionnaire. Of these, 146 were returned, 34 of which were invalid for analysis because of respondent error, as they were unwilling to participate in the research project. Of the 112 valid responses, 44 were female and 68 were male, and 65 were accounting majors and 47 were non-accounting majors.

Table 1. Sample and gender form for both accounting and non-accounting

\begin{tabular}{lllll}
\hline & & Accounting & Non-Accounting & Total \\
\hline \multirow{2}{*}{ Gender } & Male & $48(73.8 \%)$ & $20(42.6 \%)$ & $68(60.7 \%)$ \\
& Female & $17(26.2 \%)$ & $27(57.4 \%)$ & $44(39.3 \%)$ \\
Total & & $65(100.0 \%)$ & $47(100.0 \%)$ & $112(100.0 \%)$ \\
\hline
\end{tabular}

The author created the questionnaire measuring instrument to collect primary data specifically for this research project. This instrument included 28 statements divided into five groups: an instructor and his or her teaching style, exams and quizzes, the student, accounting textbooks and general groups. In addition, the questionnaire included an open-ended question. Survey participants for this study responded using a four-point scale, with items ranging from (1) strongly agree, (2) agree, (3) disagree, to (4) strongly disagree. Because of the study's goal, we put "agree" and "strongly agree" in the agreement set, and "disagree" and "strongly disagree" in the disagreement set.

After the survey was completed and tested, it was distributed to a random sample. The survey was conducted on the fall of 2007 for advanced accounting and non- accounting major.

\section{Results}

Table 2 presents a summary of responses to the 28 items listed on the questionnaire and to the open-ended question for both accounting and non-accounting majors. In this analysis, we combined responses of both accounting and non-accounting majors.

Table 2. Perception of students regarding obstacles influencing their academic achievements (In percentages)

\begin{tabular}{|c|c|c|c|c|c|c|}
\hline \multirow{2}{*}{ Items } & \multicolumn{2}{|c|}{ Accounting } & \multicolumn{2}{|c|}{ Non-Accounting } & \multicolumn{2}{|c|}{ Total } \\
\hline & Agree & Disagree & Agree & Disagree & Agree & Disagree \\
\hline \multicolumn{7}{|l|}{$\begin{array}{l}\text { Panel A: section related to an instructor and } \\
\text { his teaching style }\end{array}$} \\
\hline 1- Lack of teaching assistants & 90.8 & 9.2 & 85.1 & 14.9 & 88.4 & 11.6 \\
\hline 2- Computerized practice set is not used. & 80 & 20 & 78.7 & 21.3 & 79.5 & 20.5 \\
\hline 3- Traditional pedagogical Techniques & 81.6 & 18.4 & 74.5 & 25.5 & 78.6 & 21.4 \\
\hline 4- $\quad$ Limited Office hours & 80 & 20 & 61.7 & 38.3 & 72.3 & 27.7 \\
\hline 5- Complexity of accounting teaching & 63 & 37 & 63.8 & 36.2 & 63.4 & 36.6 \\
\hline 6- A non-objective evaluation & 50.8 & 49.2 & 66 & 34 & 57.1 & 42.9 \\
\hline 7- $\begin{array}{l}\text { Collection the homework without an } \\
\text { evaluation }\end{array}$ & 47.7 & 52.3 & 46.8 & 53.2 & 47.3 & 52.7 \\
\hline \multicolumn{7}{|l|}{$\begin{array}{l}\text { Panel B: section related to the exams and } \\
\text { Quizzes }\end{array}$} \\
\hline 8- $\quad$ Difficult exams & 73.9 & 26.1 & 70.2 & 29.8 & 72.3 & 27.7 \\
\hline 9- $\quad$ Few Homework & 70.7 & 29.3 & 70.2 & 29.8 & 70.5 & 29.5 \\
\hline 10- Few quizzes & 69.2 & 30.7 & 57.4 & 42.5 & 64.3 & 35.7 \\
\hline $\begin{array}{l}\text { 11- some questions are not covered in a } \\
\text { semester }\end{array}$ & 56.9 & 43.1 & 55.3 & 44.7 & 56.2 & 43.8 \\
\hline 12- A lot of multiple choices questions & 50.8 & 49.2 & 53.2 & 46.8 & 51.7 & 48.3 \\
\hline 13- Quizzes have an insignificant reward & 29.2 & 70.8 & 46.8 & 53.2 & 36.6 & 63.4 \\
\hline Panel C: Section related to the student & & & & & & \\
\hline
\end{tabular}




\begin{tabular}{|c|c|c|c|c|c|c|}
\hline 14- Lack of English language proficiency & 80 & 20 & 97.9 & 2.1 & 87.5 & 12.5 \\
\hline $\begin{array}{l}\text { 15- Student's motivation to learn is not } \\
\text { supported by instructor's learning style }\end{array}$ & 83 & 17 & 83 & 17 & 83 & 17 \\
\hline $\begin{array}{l}\text { 16- Student devoted less time for solving } \\
\text { accounting problems }\end{array}$ & 66.1 & 33.9 & 68.1 & 31.9 & 67 & 33 \\
\hline 17- Rarely usage of a library & 66.2 & 33.8 & 63.8 & 36.2 & 65.2 & 34.8 \\
\hline $\begin{array}{l}\text { 18- Bad study's habits (study only in the } \\
\text { night before the exam) }\end{array}$ & 64.7 & 35.3 & 53.2 & 46.8 & 59.8 & 40.2 \\
\hline $\begin{array}{l}\text { 19- Student's effort into the course is not } \\
\text { sufficient. }\end{array}$ & 63 & 37 & 48.9 & 51.1 & 57.2 & 42.8 \\
\hline $\begin{array}{l}\text { 20- Students are not aware the role of } \\
\text { accounting career }\end{array}$ & 53.9 & 46.1 & 51.1 & 18.9 & 52.7 & 47.3 \\
\hline 21- poor class attendance & 35.3 & 64.7 & 32 & 68 & 34 & 66 \\
\hline \multicolumn{7}{|l|}{ Panel D: Accounting Textbooks } \\
\hline 22- The gap among theory and practice & 86.2 & 13.8 & 85.1 & 14.9 & 85.7 & 14.3 \\
\hline $\begin{array}{l}\text { 23- The material covered during the course } \\
\text { is too lengthy. }\end{array}$ & 80 & 20 & 83 & 17 & 81.2 & 18.8 \\
\hline $\begin{array}{l}\text { 24- irrelevant textbooks to the Libyan } \\
\text { environment }\end{array}$ & 73.9 & 26.1 & 70.2 & 29.8 & 72.4 & 27.6 \\
\hline 25- A few references & 64.6 & 35.4 & 78.7 & 21.3 & 70.6 & 29.4 \\
\hline \multicolumn{7}{|l|}{ Panel E: General Factors } \\
\hline 26- Crowded of dormitories & 90.8 & 9.2 & 82.9 & 17.1 & 87.5 & 12.5 \\
\hline $\begin{array}{l}\text { 27- Absence Interaction among a student } \\
\text { and a faculties }\end{array}$ & 73.8 & 26.2 & 91.5 & 8.5 & 81.3 & 18.7 \\
\hline $\begin{array}{l}\text { 28- Negative attitude towards accounting as } \\
\text { a difficult subject }\end{array}$ & 69.2 & 30.8 & 70.2 & 29.8 & 69.6 & 30.4 \\
\hline
\end{tabular}

Panel A of Table 2 shows that over 63\% of the respondents of both groups (accounting and non-accounting majors) think that the biggest obstacles to instruction is lack of teaching assistants, computerized practice sets are not used, traditional pedagogy, limited office hours, and complexity of accounting. $90 \%$ of accounting majors think the lack of teaching assistants is the main obstacle while only $62 \%$ of non-accounting majors think limited office hours is the primary obstacle.

An examination of panel B of Table 2 demonstrates that over $64 \%$ of both intended accounting and non-accounting majors believe that the main obstacles are difficult exams, fewer homework assignments, and fewer quizzes. Both groups have an identical view regarding fewer homework assignments; however, $74 \%$ of accounting majors think the main obstacle is unreasonable exams.

Results related to panel C of Table 2 illustrate that over $65 \%$ of both groups believe the most important obstacle related to students' effort is the lack of English language proficiency. The data shows that students are not highly motivated by the instruction style and devoted less time for solving accounting problems and rarely used the library. The vast majority $98 \%$ of non-accounting majors believe that poor English skills is the main obstacle to learning accounting, while only $63 \%$ of the accounting group perceives that the student's effort in the course is not sufficient.

Results related to panel D of Table 2 show that over $71 \%$ of both groups agree that accounting textbooks have major influence on their academic performance; $86 \%$ of the accounting major group agrees that there is a wide gap between theory and practice; and also $65 \%$ of the same group indicated too few references.

Nearly $70 \%$ of both groups agreed that crowded dormitories, absence of interaction among students and faculty, and the perception of accounting as a difficult subject are major obstacles for learning accounting.

There doesn't seem to be any coherent responses that can be drawn from the open-ended question, except that most agree that instructors' effort is insufficient. 


\section{Discussion}

\subsection{Narrative of Obstructions to Teaching Techniques}

The study indicated that the biggest obstacles to academic achievement are the lack of teaching assistants, and lack of computerized practice sets. A lack of teaching assistants prevented students from receiving extra help outside of class and in small groups, as well as a void in advice to improve their critical thinking skills. Having teaching assistants is very important not only for students, but also for faculty. They can help the instructors by observing the class during daily instruction and noticing students who are struggling. Likewise, they can help students who are excelling to advance to the next level. This research also pointed out that computerized practice sets are not being used. This means that the accounting cycle is taught and executed in classrooms manually, which fosters the false perception among students that practice sets require much more time than they actually do when the process is automated. Thus, results suggest that having computers with relevant software in the classrooms, as well as the aid of teaching assistants, will make a dramatic difference in student performance, and reduce the current effort required.

Historically, there was no evidence that computing is relevant to learning accounting concepts (Baxter, 1974; Arnett, 1974; Abraham, 1987; Er, 1989; T, 1973) However, once computers became common place in colleges and universities, Kachelmeier et al. (1992) observed that students who used computer applications, such as spreadsheets, did better in examinations than those who did not. Furthermore, in 1985, the American Accounting Association (AAA) recognized the importance of integrating computers and computer applications in undergraduate financial accounting programs (Al-Khadash \& Al-Bishtwawi, 2010). So, it is recommended that the College of Accounting at Al-Jabal Al-Gharbi University should have a policy for integrating computers beginning with the core accounting courses.

\subsection{Narrative of Quizzes and Exams}

Findings confirmed that students received too few homework assignments and quizzes, and that exams were too difficult. The fact that respondents found the exams cumbersome is logical given the lack of teaching assistants. When students did not get any help and tried to figure out everything by themselves, they indicated that the exam was too hard. Respondents also expressed that by having only a few homework assignments and quizzes which hindered them from more fully understanding the material. Applying a variety of teaching methods such as exams, homework assignments, and quizzes might play a big role in changing students' attitude toward accounting, and help improve their academic achievements. It is essential for faculty to have teaching assistants so that they will be able to assign more homework and quizzes, and to help them assess student performance and offer additional instruction so they can achieve a higher level of understanding. Multiple studies have confirmed these findings, which one of the main obstacles to student success is the lack of homework and quizzes, which would reinforce the course material, allowing students to score higher on exams (Porter and Lawler, 1968; Reed et al., 1989; Elikai and J, 1989; Almer et al., 1998). Thus, the College of Accounting should implement a variety of teaching methods, such as homework assignments, quizzes, case analysis, class discussions, etc., to enhance student performance. Additionally, the rewards or points assigned to quizzes should contribute significantly to the course grade. Daily quizzes should not be used solely to get students to attend classes regularly, but rather as a teaching tool.

\subsection{Narrative of Student Effort}

Research concluded that one of the biggest obstacles related to student effort is the lack of English language proficiency. English was not allowed to be the second language in the Libyan education system, based on a decision by a Minster of education in the mid-80s, which eliminated all foreign language curricula from primary to post-graduate education. Since most accounting literature is transferred to the students via the English language, students still believe that their poor performance in English language is a major cause of influence on academic achievement. They have this impression despite the fact that there are a lot of accounting textbooks which have written in Arabic language. The impact of the foreign language on the student's performance was confirmed also by (Ayers and Peters, 1977; Atieh, 1997).

\subsection{Narrative of Accounting Textbooks}

Findings showed that poorly chosen accounting textbooks have a major negative influence on academic performance. In this case, respondents felt that there was a wide gap between the curricula content, as presented in the course books, and the actual role of accounting profession in Libya. Libyan graduates have been prepared with specified and standardized accounting techniques which are not available in real life. This result is consistent with Flaherty and Diamond (1996), who observed that accounting programs should prepare students 
to become professional accountants, not to be professional accountants at the time of entry to the profession. In this regard, it is important to indicate that most accounting textbooks used in Libya were written or translated by Libyan experts who graduated from U.S. colleges. So, the culture they inherited from the American environment is reflected in their publications with little concern to the Libyan environment. Although Western accounting courses introduced in Libya have had a positive impact on students' knowledge and accounting practices, these courses are not easily understood by Libyan students. For example, since enterprises in Libya are totally owned and controlled by the government-whereas the agent-principal problem that has existed in the West seems absent - students find it very difficult to understand the agency issues at the heart of many Western accounting and finance textbooks. The accounting system in Libya is based on Islamic philosophy, which is quite different from the widespread Western philosophy. Under the concept of Islamic law, Shari'a, social responsibility is required, rather than the predominant personal accountability found in Western societies and accounting practices. Thus, accounting textbooks should discuss the need to include social responsibility in full disclosure requirements. Similarly, they should address the impact of Arab culture, and its strong social relations in particular, on auditor independence by extending and adopting a code of ethics for a more communal society, rather than an individualistic Western society. Another outcome of this study was the perception that there was too much material covered during the semester. It is not surprising that Libyan students complained about limited or no study time, a factor related to common issues of poor study skills, poor time-management, and the habit of not studying or reviewing materials for exams ahead of time.

\section{Research Limitations}

It is essential to be aware of the limitations inherent within this study. First, because this study was conducted in only one public university, the results may not necessarily be extended to other universities. Second, although the author has experience as a Libyan accounting graduate student and as a full-time lecturer at the College of Accounting at Al-Jabal Al-Gharbi University, his experience was not used to analyze and discuss the research finding.

\section{Implications of this Research}

This study identified and listed some academic obstacles in fundamental accounting courses in one developing country. This research contributes significantly to existing literature by providing background information about Libyan business education, which might be useful for international readers.

An accounting education system consists of students, faculty, curriculum, and resources (library, labs, technology) that are ideally and effectively combined to meet educational needs. The most important implications for Al-Jabal Al-Gharbi University and its accounting instructors are that they should target the components listed below:

First, accounting students at Al-Jabal Al-Gharbi University should be prepared for a number of jobs by learning Computerized Accounting Technology. As the first step, they should at least know and be able to use specialized accounting software, spreadsheets, and databases. This is very important to their future career options, and will eliminate negative perceptions of accounting as a difficult subject which consumes too much time.

Second, instructors play a significant role in any educational system. So, improving the effectiveness of accounting instructors will enhance student's achievements. By increasing salaries, professors will have time to update the curriculum, conduct more research, advise students, and--most importantly--write accounting textbooks focused on the accounting needs of the Libyan environment.

Third, this study indicated that students have a pre-conception of accounting as a very difficult subject. This negative and false perspective was formed by their experiences in high school. Teaching some basic business courses in high school or pre-college might help eliminate the negative attitude towards accounting and improve student's academic achievements in the foundation accounting courses.

\section{Application for Future Research}

Because the primary data used in this report was collected in 2007, the author gave significant concern and attention to any changes that may have occurred in Libya's education system in general and accounting education in particular. The researcher gathered additional data — the final grades from 2008 to 2012 - in order to ensure that the findings were consistent. This data is presented in Table 3 and 4, and shows that the percentage of students who failed and got low grades in Principle of Accounting 130 ranged from $17 \%$ to $77 \%$ and in Principle of Accounting 131 ranged from $27 \%$ to 61 . To measure the low performance of students, we used grades D and $\mathrm{D}^{+}$(1 and 1.5 points, or 50-54 and 55-59). These grades indicate a minimum knowledge of the principles of accounting. This confirms and substantiates the researcher's problem and hopefully inspires other researchers to 
extend this study by conducting similar studies which focus on and investigate the instructor's perception toward teaching in introductory accounting courses at Al-Jabal Al-Gharbi University. To explore more extensively the difficulty of academic achievement in the area of accounting, it is recommended that researchers request student interviews after collecting the completed questionnaires. The interviews will help the researcher to elicit more complete responses. Significant attention should be given to perspectives based on gender, as this research intends to contribute to the discovery and understanding of any differences in classroom performance among male and female students. This study pointed out that $72 \%$ of respondents think that the most important obstacle to academic success is difficult exams. This result needs to be proven by studying the relationship between the students' academic achievements in introductory courses and their GPAs. In this endeavor, studying the GPA in the Principles of Accounting courses is the best predictor of a successful student.

Table 3. Students registered in Principle of Accounting 130

\begin{tabular}{|c|c|c|c|c|c|}
\hline \multirow[t]{2}{*}{ Year } & \multirow[t]{2}{*}{ No } & \multicolumn{2}{|c|}{ Fail } & \multicolumn{2}{|c|}{ Low performance (D and $\left.\mathrm{D}^{+}\right)$} \\
\hline & & No & $\%$ & No & $\%$ \\
\hline \multicolumn{6}{|l|}{$2008-2009$} \\
\hline Fall & 195 & 56 & 29 & 34 & 17 \\
\hline Spring & 167 & 100 & 60 & 42 & 25 \\
\hline Total & 362 & 165 & 45 & 76 & 21 \\
\hline \multicolumn{6}{|l|}{$2009-2010$} \\
\hline Fall & 160 & 103 & 64 & 27 & 17 \\
\hline Spring & 82 & 63 & 77 & 16 & 19 \\
\hline Total & 242 & 166 & 68 & 43 & 18 \\
\hline \multicolumn{6}{|l|}{$2010-2011$} \\
\hline Fall* & 63 & 44 & 70 & 21 & 33 \\
\hline \multicolumn{6}{|l|}{ 2011-2012 } \\
\hline Fall & 64 & 28 & 44 & 26 & 40 \\
\hline Spring & 159 & 100 & 63 & 38 & 24 \\
\hline Total & 223 & 128 & 57 & 64 & 29 \\
\hline \multicolumn{6}{|l|}{$2012-2013$} \\
\hline Fall & 169 & 85 & 50 & 40 & 24 \\
\hline
\end{tabular}

Table 4. Students registered in Principle of Accounting 131

\begin{tabular}{|c|c|c|c|c|c|}
\hline \multirow[t]{2}{*}{ Year } & \multirow[t]{2}{*}{ No } & \multicolumn{2}{|c|}{ Fail } & \multicolumn{2}{|c|}{ Low performance ( $\mathrm{D}$ and $\left.\mathrm{D}^{+}\right)$} \\
\hline & & No & $\%$ & No & $\%$ \\
\hline \multicolumn{6}{|l|}{$2008-2009$} \\
\hline Fall & 18 & 11 & 61 & 6 & 33 \\
\hline Spring & 89 & 26 & 29 & 40 & 45 \\
\hline Total & 107 & 37 & 34 & 46 & 43 \\
\hline \multicolumn{6}{|l|}{$2009-2010$} \\
\hline Fall & 113 & 65 & 57 & 35 & 31 \\
\hline Spring & 123 & 67 & 54 & 44 & 36 \\
\hline Total & 236 & 132 & 60 & 97 & 41 \\
\hline \multicolumn{6}{|l|}{$2010-2011$} \\
\hline Fall* & 92 & 33 & 36 & 41 & 44 \\
\hline \multicolumn{6}{|l|}{ 2011-2012 } \\
\hline Fall & 71 & 19 & 27 & 35 & 49 \\
\hline Spring & 32 & 12 & 37 & 16 & 50 \\
\hline Total & 103 & 31 & 30 & 51 & 49 \\
\hline \multicolumn{6}{|l|}{$2012-2013$} \\
\hline Fall & 77 & 23 & 30 & 23 & 30 \\
\hline
\end{tabular}

* Because of the Libyan revolution and civil unrest, students could not attend the classes in spring 2011. 


\section{Concluding Remarks}

This research empirically investigated student perceptions of the difficulties of academic achievement in Principles of Accounting courses in the College of Accounting at Al-Jabal Al-Gharbi University, Libya.

The results of this study indicate that the major obstacles to learning, and the source of negative perceptions students have toward accounting courses, are lack of teaching assistants, lack of computer laboratories and computer applications, crowded dormitories, lack of interaction between students and faculty, a gap between what is taught and practical application, lack of relevant textbooks and exams, and lack of students' English language proficiency.

These findings cannot be generalized to all public business schools in Libya. It might be instructive to conduct the same, or similar, study in other business schools so that a universal set of solutions can be established to improve business education in Libya.

\section{Acknowledgements}

I wish first to state my gratitude to Allah who gave me the knowledge and effort to achieve this paper. While writing this manuscript, I received help from Dr. E.K. Esawi, and without him this article could not have been finished. Mentioning him here is the least I can do to express my gratitude to Dr. Esawi. The author also appreciates Nicole Marsh for her valuable help in the preparation of this paper for publication.

\section{References}

Abraham, E. C. (1987, Spring). Computerized practice set in introductory financial accounting. Issues in Accounting Education, 2(1), 1-12. Retrieved from http://hdl.handle.net/1882/21673

Ahmed, N. S. (2004). Cororate environment discloserure in Libya: Evidence and environment determinism theory. Retrieved from http://researchrepository.napier.ac.uk/2784/1/AhmadPhD410769.pdf

Ahmed, N. S., \& Gao, S. S. (2004, September). Changes, problems and challenges of accounting education in Libya. Accounting Education, 13(3), 365-390. http://dx.doi.org/10.1080/0963928042000273825

Al-Daly, M. M. (2003). The key role of the Libyan business education program to enhance the student performance in undergraduate accounting courses (Master thesis, the Libyan Academy, Tripoli, Libya).

Al-Hanon, H. (2004). Reasons not to take advantage of the body of knowledge gained for the graduate (Master thesis, College of economic, Benghazi, Libya).

Al-Kalian, A.-K. A. (2000). The relationship between business education and the Libyan economic and social developments. Journal of Economic Research.

Al-Khadash, H. A., \& Al-Bishtwawi, S. (2010, September). The Impact of Accounting Software Utilization on Accounting Students Perceived Skills. Middle Eastern Finance and Economics, 2010(7), 140-148. Retrieved from http://www.eurojournals.com/MEFE.htm

Almer, E. D., Jones, K., \& Moeckel, C. L. (1998, August). The impact of one-minute papers on learning in an introductory accounting course. Issues in Accounting Education, 13(3), 485-497. Retrieved from http://aaahq.org/pubs/issues.htm

Atieh, S. H. (1997). Student perceptions of the causes of low performance in principles of accounting: A case study in saudi Arabia. Journal of King Fahd University: Economics \& Administration, 10, 35-50. http://dx.doi.org/10.4197/Eco.10-1.2

Austin, A. M., \& Gustafson, L. (2006, Summer). Impact of course length on student learning. Journal of Economics and Finance Education, 5(1), 26-37. Retrieved from http://www.economics-finance.org/jefe/issues/vol5summer.pdf

Ayers, J. B., \& Peters, R. M. (1977, July). Productive validity of the test of english as foreign language for asian graduate students in engineering, chemistry, or mathematics. Educational and Psychological Measurement, 37(2), 461-463. http://dx.doi.org/10.1177/001316447703700221

Bait-EL-Mal, M. M., Smith, M. M. H. C., \& Taylor, M. E. (1973). The development of accounting in Libya. International Journal of Accounting Education and Resaerch, 83-102.

Baxter, C. A. (1974). The effects of computer augmented instruction on achievement in the collegiate principles of accounting course (Ed. D thesis, University of Georgia).

Beets, S. D., \& Lobingier, P. G. (2001, Mar-Apr). Pedagogical technique: Students performance and preference. Journal of Education for business, 76(4), 231-235. http://dx.doi.org/10.1080/08832320109601316 
Ben-Garbia, S. M. (1990). The interest of integration among scientific research and the accounting profession and business education. Journal of Economic Research, 2(2).

Brink, A. G. (2013, August). The Impact of pre- and post-lecture quizzes on performance in intermediate accounting II. Issues in Accounting Education, 28(3), 461-485. http://dx.doi.org/10.2308/iace-50445

Buzied, M. M. (1998). Enterprise accounting and its context of operation: The case of Libya. (R. Dixon, Ed.). UK: Durham University. Retrieved from http://etheses.dur.ac.uk/1652/

El Shamy, M., Hamdalla, A., \& Al-Modaf, J. (2011, November 21-24). The determenants of student performance in advanced accounting - evidence from Kuwait. Proceedings pf Macao International Symposium on Accounting and Finance (pp. 1-15). Macao, China: Macao Polyetchinc Institute. Retrieved from http://www.macaoafa.org/proceedings/index.php/mafa/article/view/18

Elikai, F., \& Baker, J. (1988, Fall). Empirical evidence on the effectiveness of quizzes as a motivational technique. Issues in Accounting Education, 3(2), 248-254. Retrieved from http://aaahq.org/pubs/issues.htm

Er, M. A. (1989). The use of computers in accountancy courses: A new perspective. Accounting and Business Research, 19(76), 319-326. http://dx.doi.org/10.1080/00014788.1990.9728893

Flaherty, R. E., \& Diamond, M. A. (1996). Position and issues statements of the accounting education change commission, Accounting Education Change Commission and American Accounting Association. Accounting Education Series, 1996(13).

Hong, S. T. (1973). An empirical study of the effectiveness of programmed instruction and computer-assisted instruction in elementary accounting. Dissertation Abstract International, 322.

Jochems, W. (1991). Effects of learning and testing in a foreign language. European Journal of Engineering Education, 16(4), 309-316. http://dx.doi.org/10.1080/03043799108939537

Kachelmeier, S. J., Jones, J. D., \& Keller, A. J. (1992, Fall). Evaluating the effectiveness of a computer intensive learning aid for teaching pension accounting. Issues in Accounting Education, 7(2), 164-178. Retrieved from http://aaahq.org/pubs/issues.htm

Kilani, K. A. (1988). The evolution and status of accounting in Libya (Doctoral thesis, the University of Hull, UK).

Kilani, K. A. (2000). The relationship between business education and the Libyan economic and social developments. Journal of Economic Research, 11(1-2).

Nouri, H., \& Shahid, A. (2008). The effects of powerpoint lecture notes on student performance and attitudes. The Accounting Educators' Journal, 18, 103-117. Retrieved from http://www.aejournal.com/ojs/index.php/aej/article/view/99

Ogilby, M. A. (2000). The first course in accounting: Students' perceptions and their effect on the decision to major in accounting. Journal of Accounting Education, 18(2), 63-78. http://dx.doi.org/10.1016/S0748-5751(00)00011-7

Okafor, C. A. (2011, June). Academic performance of male versus female accounting undergraduate students: Evidence from Nigeria. Higher Education Studies, 1(1), 9-19. http://dx.doi.org/10.5539/hes.v1n1p9

Porter, L. W., \& Lawler, E. E. (1968). Managerial attitudes and performance. (C. P. Alderfer, Ed.). Homewood, Illinois, US.

Reed, S. A., \& Holley, J. M. (1989, Fall). The effect of final examination scheduling on student performance. Issues in Accounting Education, 4(2), 327-344. Retrieved from http://aaahq.org/pubs/issues.htm

Sayel, R., \& Quraan, A. (1994). Determinats of students' performance in introductory accounting courses. $J$. Knig Soud Univ, 6(2), 65-80.

Shareia, B. (2010). The Libyan accounting profession: Historical factors and economic consequences. Retrieved from

http://apira2010.econ.usyd.edu.au/conference_proceedings/APIRA-2010-091-Shareia-The-Libyan-accounti ng-profession.pdf

Solomon, L. (1975). Improving student attitude in the beginning accounting course. The Accounting Review, 50(3), 601-605. Retrieved from http://www.jstor.org/stable/245021 
Weinstein, L. P. (1999). Student performance in introductory accounting: A multi-sample, multi-model analysis. Accounting Educators' Journal, XI, 1-28. Retrieved from http://www.aejournal.com/ojs/index.php/aej/article/view/11

Williams, L. K. (1991). A synthesis of research studies on the performance of male and female accounting. The Woman CPA, 53(2), 12-15.

Young, J. (2004, November 12). When good technology means bad teaching: Giving professors gadgets without training can do more harm than good in the classroom, students say. The Chronicle of Higher Education, 51(12). Retrieved from http://chronicle.com/article/When-Good-Technology-Means-Bad/10922/

\section{Copyrights}

Copyright for this article is retained by the author(s), with first publication rights granted to the journal.

This is an open-access article distributed under the terms and conditions of the Creative Commons Attribution license (http://creativecommons.org/licenses/by/3.0/). 